\title{
Comparative Studies on Rubber Biodegradation by Mixed Culture and Pure Culture Isolated From the Soil Samples
}

\author{
Chairat Nawong, Natthawan Sermwittayawong, and Kamontam Umsakul
}

\begin{abstract}
An increasing production of natural rubber (NR) compounds has led to major challenges in waste management. The degradation of NR is normally extremely slow. In this study, the degradation of rubber latex gloves in a mineral salt medium (MSM) using a mixed culture of the selected bacteria and a pure culture was investigated by monitoring weight loss, scanning electron microscopy (SEM) and viable cell counts. About $18 \%$ weight loss of the rubber gloves were detected after incubated with the mixed culture and the pure culture. The increased viable cell counts over incubation time indicated that cells used rubber gloves as a carbon source leading to the degradation of the polymer. The degradation of NR gloves was also determined by observing the growth of NR-degrading bacteria on the glove surface using SEM.
\end{abstract}

Keywords - Biodegradation, natural rubber, latex glove.

\section{INTRODUCTION}

Natural rubber is a polymer that is produced from several plant species. The main composition of natural rubber latex is poly-1, 4 isoprene that consists of isoprene as a monomer. In nature, poly isoprene can be divided into two groups, poly-cis isoprene and poly tran isoprene. Natural rubber is mainly produced from the Hevea brasiliensis. However, not only Hevea brasiliensis but also many plants can produce latex [16]. In addition, they are an alternative rubber such as Ficus elastica, Ficus nitida and Euphorbia pulcherrima [9]. The latex from the Hevea brasiliensis contains a polymer of cis-1, 4-polyisoprene units. Up to $90 \%$ of the dry weight of the latex is cis-1, 4-polyisoprene and less than $10 \%$ is non-rubber constituents such as protein, and carbohydrates [17].

Global natural rubber production increased to 12.2 million metric tons in 2013, a rise of $79.4 \%$ from 6.8 million metric tons in 2000 [18]. These polymers can be used in thousands of ways i.e. in the fabrics, mining, power generation, agriculture, transportation, paper industries, insulation of cables, wires, and various equipments, in addition, it is the major component in rubber tires [16]. However, billions of discarded tires are currently stockpiled around the world and these are increasing exponentially and causing important environmental problems.

Chairat Nawong (Author), Prince of Songkla University, Thailand Natthawan Kongkerd, Prince of Songkla University, Thailand Kamontam Umsakul, Prince of Songkla University, Thailand
At present, much rubber waste is eliminated by either burned or used as landfills, but this process can cause serious pollution [6].

Biodegradation is the degrading process by microorganisms. Roles of microbes in degradation process are releasing of an extracellular enzyme to cleave polymer chain into small molecules and these products are absorbed into the cell for use as carbon and energy source. Final process, $\mathrm{CO}_{2}, \mathrm{H}_{2} \mathrm{O}$ and other metabolic products are released and they can be used for photosynthesis by the plants. Therefore, the biodegradation is an alternative way to degrade the rubber waste and could overcome these environmental problems [2], [3].

However, microbial degradation of polyisoprene rubber is a very slow process that is taking months or even years. Microbial degradation of poly (cis-1, 4-isoprene) rubber is currently being intensively investigated. So far rubberdegrading organisms have been classified into two different groups; the first group is rubber-degrading organisms producing clear zones on natural rubber latex agar plates. Members of these groups generally belong to the myceliumforming actinomycetes such as Actinoplanes, Streptomyces, and Micromonospora. In contrast, the second group of rubberdegrading organisms is the organisms which cannot produce any clear zone, therefore they require the direct contact with the rubber substrates. The example of this group is nocardioform, actinomycetes i.e. Gordonia, Mycobacterium and Nocardia. Xanthomonas sp. strain $35 \mathrm{Y}$ is the only known gram-negative rubber degrading bacterium which does not belong to the actinomycetes [13].

In this study, the degradation of rubber latex gloves in a mineral salt medium (MSM) by a mixed culture of the selected bacteria and a pure culture was compared. The weight loss, scanning electron microscopy (SEM) of the rubber glove substrate and viable cell counts were determined.

\section{METHODS}

\section{A. Isolation of rubber degrading microorganisms from soil samples by enrichment culture technique}

The rubber-degrading microorganisms were isolated from soil samples collected from various contaminated rubber sites in Songkhla, Thailand. Approximate ten grams of the soils mixed with pieces of natural rubber (NR) glove were added to 
$100 \mathrm{~mL}$ of sterile mineral salt medium (MSM) in each Erlenmeyer flask and were then incubated at $30^{\circ} \mathrm{C}$ at $150 \mathrm{rpm}$. Mineral salt medium is composed of $(\mathrm{g} / \mathrm{L}): \mathrm{Na}_{2} \mathrm{HPO}_{4}$ 9.0, $\mathrm{KH}_{2} \mathrm{PO}_{4} 1.5,(\mathrm{NH} 4)_{2} \mathrm{NO}_{3} 1.0, \mathrm{MgSO}_{4} 0.2, \mathrm{CaCl}_{2} \quad 0.02$, and $\mathrm{Fe}(\mathrm{III}) \mathrm{NH}_{4}$ 0.0012. The medium was adjusted to an initial $\mathrm{pH}$ of 7.0 before sterilization. After a month of incubation, $0.5 \mathrm{~mL}$ of each culture broth was transferred into a new flask containing fresh MSM with NR glove and further incubated under the same conditions as described above for another month to encourage the rubber degrading bacteria to grow. The developed culture broth was then assigned as the natural soil consortia and stored in $15 \%$ glycerol at $-80^{\circ} \mathrm{C}$. The rubber degrading bacteria were also screened and isolated from the culture broth using NR latex agar plates.

\section{B. Screening of NR-degrading bacteria}

The degradation of the rubber gloves by the selected strains was investigated through plate assay. Latex overlay plates were prepared by spreading $5 \mathrm{~mL}$ of solubilized latex concentrate as a thin film on MSM agar plates and then left it to evaporate until dried. All tested strains that grew well on the latex overlay agar were picked for further study.

\section{Rubber glove degradation of the individual tested bacteria and the mixed culture}

Latex glove pieces were washed once with distilled water prior to drying in an oven at $60{ }^{\circ} \mathrm{C}$ until obtained a constant weight before being used as a carbon source. Two experiments were designed to test the microbial activities for degrading rubber gloves. The first experiment was testing each individual isolated strain and the second experiment was the randomly mixed cultures of isolated strain. Each culture was incubated in MSM supplemented with dried latex glove piece $(0.6 \% \mathrm{w} / \mathrm{v})$ as a sole carbon source and were incubated at $30{ }^{\circ} \mathrm{C}, 150 \mathrm{rpm}$ for 4 weeks. This experiment was performed in triplicate. The inoculated MSM without any latex glove pieces and the noninoculated MSM with latex glove pieces were used as control experiments. Viable cell counts of each culture were determined throughout the incubation time. Weight loss of incubated latex gloves at the end of incubation period was measured and calculated in gram unit.

\section{Scanning Electron Microscope (SEM)}

The surface of the latex glove film pieces from the inoculated samples and the control were analyzed by scanning electron microscopy (SEM) to investigate the surface changes after the degradation. The samples were washed with sterilized distilled water and then were mounted on aluminum stubs. Gold coating was carried out in vacuum by evaporation to make the samples conducting. SEM images of the tested and control samples were compared.

\section{RESULT AND DISCUSSION}

\section{A. Isolation of rubber-degrading microorganisms from soil} samples

Ten bacterial isolates, F1 to F10, obtained from soil samples were capable of growing on MSM agar containing NR. Isolate F5 and F7 were identified as Gram-positive and others were
Gram-negative bacteria. All ten isolates did not produce clearing zone around the colonies indicated that they could degrade the latex concentrate by a production of an intracellular enzyme [16].

\section{B. Weight loss of degraded latex glove}

The weight loss of latex glove pieces after one month incubation was around $0.5-18 \%$. The highest weight loss of $18.82 \%$ received from the mixed cultures (Fig. 1) and $9.36 \%$ from the pure culture of isolate F5 compared to only $0.2 \%$ of the control samples (see Table I). Moreover, NR glove had been broken down into little pieces (Fig. 2) indicated that the bacteria had the ability to degrade natural rubber

TABLE I

WEIGHT LOSS IN LATEX GLOVE AND VIABLE CELL COUNTS OF PURE CULTURE

\begin{tabular}{|l|l|l|l|}
\hline \multirow{2}{*}{ Isolate } & \multirow{2}{*}{$\begin{array}{c}\text { Weight loss of latex } \\
\text { glove }\end{array}$} & \multicolumn{2}{c|}{ Viable cell counts $(\mathbf{C F U} / \mathrm{mL})$} \\
\cline { 3 - 4 } & $4.31 \%$ & $1.22 \times 10^{8}$ & \multicolumn{1}{c|}{ Day $3.20 \times 10^{8}$} \\
\hline F1 & $4.45 \%$ & $1.15 \times 10^{8}$ & $4.30 \times 10^{8}$ \\
\hline F2 & $3.92 \%$ & $1.21 \times 10^{8}$ & $3.00 \times 10^{8}$ \\
\hline F3 & $0.88 \%$ & $1.20 \times 10^{8}$ & $1.40 \times 10^{8}$ \\
\hline F4 & $9.36 \%$ & $1.21 \times 10^{8}$ & $1.50 \times 10^{9}$ \\
\hline F5 & $4.52 \%$ & $1.20 \times 10^{8}$ & $4.50 \times 10^{8}$ \\
\hline F6 & $4.31 \%$ & $1.26 \times 10^{8}$ & $3.40 \times 10^{8}$ \\
\hline F7 & $1.54 \%$ & $1.23 \times 10^{8}$ & $2.40 \times 10^{8}$ \\
\hline F8 & $0.53 \%$ & $1.25 \times 10^{8}$ & $1.31 \times 10^{8}$ \\
\hline F9 & $1.22 \%$ & $1.19 \times 10^{8}$ & $2.10 \times 10^{8}$ \\
\hline F10 & $0.20 \%$ & 0.00 & 0.00 \\
\hline Control & & \multicolumn{2}{|c|}{} \\
\hline
\end{tabular}

\section{Viable cell counts}

Mixed culture grew well with the highest viable cell count of $6.20 \times 10^{9} \mathrm{CFU} / \mathrm{mL}$ (see Table II). The best growth related to the highest weight loss of latex glove pieces among selected strains. The increased viable cell counts through the end of the incubation time indicated that the bacteria had the ability to degrade natural rubber and used rubber gloves as the sole carbon source.

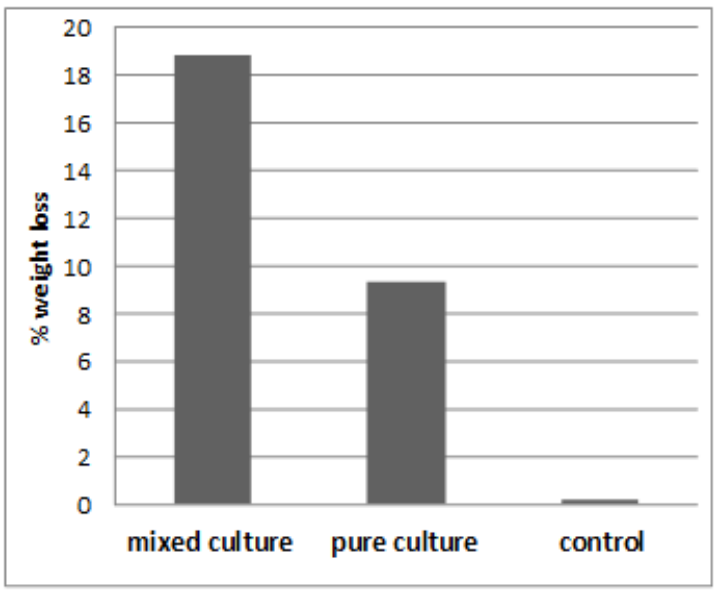

Fig. 1 Percentage weight loss of rubber gloves after incubation with various inocula. 
TABLE II

WEIGHT LOSS IN LATEX GLOVE AND VIABLE CELL COUNTS OF VARIOUS INOCULA

\begin{tabular}{|l|c|c|c|}
\hline \multirow{2}{*}{\multicolumn{1}{|c|}{ Isolate }} & \multirow{2}{*}{$\begin{array}{c}\text { Weight loss } \\
\text { of latex } \\
\text { glove }\end{array}$} & \multicolumn{2}{c|}{$\begin{array}{c}\text { Viable cell counts } \\
\text { (CFU/mL) }\end{array}$} \\
\cline { 3 - 4 } & $18.82 \%$ & $1.15 \times 10^{\mathrm{s}}$ & $6.20 \times 10^{\circ}$ \\
\hline mixed culture & $9.36 \%$ & $1.21 \times 10^{\mathrm{s}}$ & $1.50 \times 10^{\circ}$ \\
\hline $\begin{array}{l}\text { pure culture } \\
\text { (F5) }\end{array}$ & $>5.00 \%$ & $1.20 \times 10^{\mathrm{s}}$ & $>1.00 \times 10^{\circ}$ \\
\hline $\begin{array}{l}\text { pure culture } \\
\text { (other strains) }\end{array}$ & $0.20 \%$ & 0.00 & 0.00 \\
\hline control & & & \\
\hline
\end{tabular}

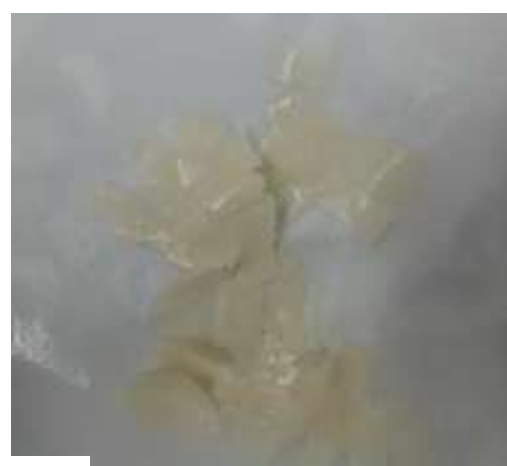

(a)

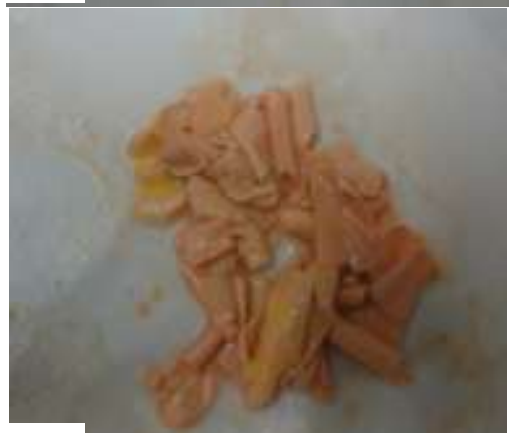

(b)

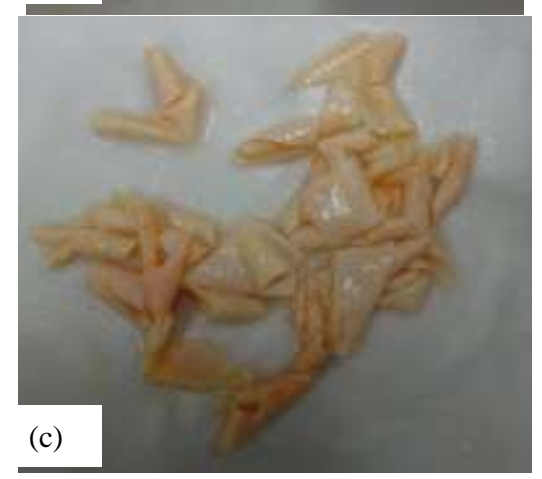

Fig. 2 Image of the latex glove pieces after incubation for 30 days: (a) control, (b) mixed culture and (c) pure culture (isolate F5).

\section{SEM}

Fig. 3a shows the surface of the control piece of NR glove (uninoculated). They were smooth without any pits whereas the glove pieces that were exposed to mixed culture for 30 days showed a rough appearance i.e. there were numerous irregular cracks, surface erosions, and pits in varoius sizes on the surface of polymer films (Fig. 3b). This is a similar situation to some other species e.g. Bacillus sp. AF-666 [13] and Streptomyces strain La 7 [7]. Interestingly, isolate F5 colonized not only on the surface but also deeply inside the polymer holes (Fig. 3c). The colonization and growth on the NR glove surface were confirmed by SEM and showed that there were numerous small holes on latex glove degraded by F5 than in mixed culture.

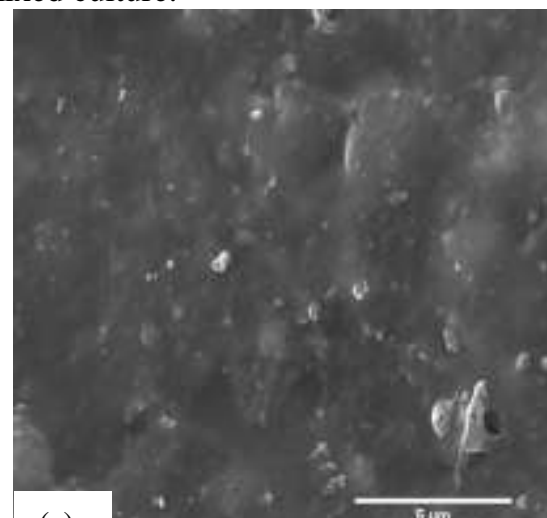

(a)

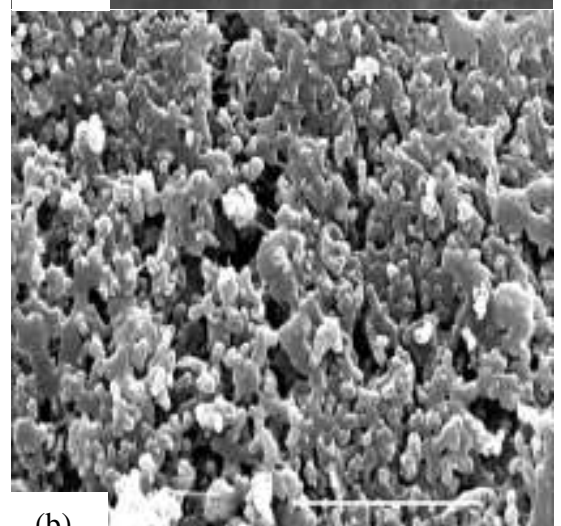

(b)

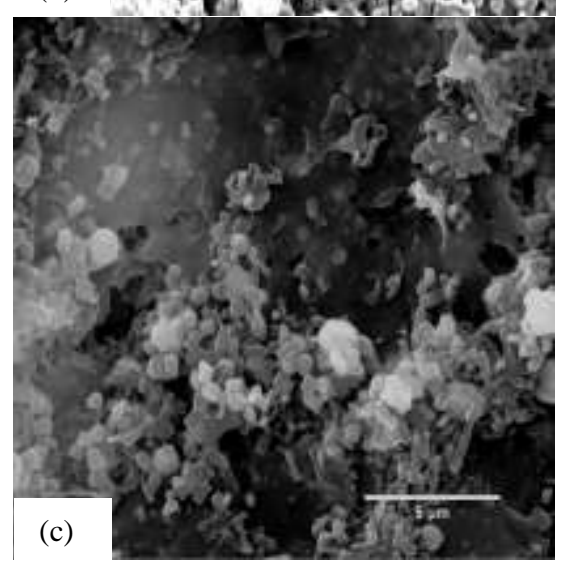

Fig. 3 Scanning electron micrographs of the latex glove pieces after incubation for 30 days: (a) control, (b) mixed culture and (c) pure culture (isolate F5).

\section{CONCLUSIONS}

In the present study, a mixed culture and pure culture were able to degrade poly (cis-1, 4-isoprene) which is the monomer compositions of rubber. The weight loss of rubber, the increase in viable cell counts and the appearance changes and the microbial growth of the NR glove surface after one-month 
incubation confirmed the biodegradation of natural rubber by these isolates. Mixed culture of the selected strains reached the highest rubber degradation with the percentage of weight loss of $18.82 \%$ after one-month incubation (Fig. 1). This mixed culture has shown the potential to be used efficiently for rubber degradation.

\section{ACKNOWLEDGMENT}

This work is financially supported by Research assistant scholarships, Faculty of Science, Prince of Songkla University the Faculty of Science.

\section{REFERENCES}

[1] M. M. Berekaa, "Colonization and microbial degradation of polyisoprene rubber by nocardioform actinomycete Nocardia sp. strainMBR," Biotechnology, vol. 5, 2006, pp. 234-239. https://doi.org/10.3923/biotech.2006.234.239

[2] H. B. Bode, A. Zeeck, K. Plückhahn, and D. Jendrossek, "Physiological and chemical investigations into microbial degradation of synthetic poly (cis-1, 4-isoprene)," Applied and Environmental Microbiology, vol. 66,2000 , pp.3680-3685.

https://doi.org/10.1128/AEM.66.9.3680-3685.2000

[3] HB. Bode, K. Kerkhoff, and D. Jendrossek, "Bacterial degradation of natural and synthetic rubber," Biomacromolecules, vol. 2, 2001, pp. 295-303. https://doi.org/10.1021/bm005638h

[4] R. Braaz, P. Fischer, and D. Jendrossek, "Novel type of hemedependent oxygenase catalyzes oxidative cleavage of rubber (poly-cis1,4-isoprene)," Applied and Environmental Microbiology, vol. 70, 2004, pp.7388-7395. https://doi.org/10.1128/AEM.70.12.7388-7395.2004

[5] E. Cherian, and K. Jayachandran, "Microbial degradation of natural rubber latex by a novel species of Bacillus sp. SBS25 isolated from soil," International Journal of Environmental Research, vol. 3, 2009, pp. 599-604.

[6] D. Fatta, A. Papadopoulos, and M. Loizidou, "A study on the landfill leachate and its impact on the groundwater quality of the greater area," Environmental Geochemistry and Health, vol. 21, 1999, pp.175-190. https://doi.org/10.1023/A:1006613530137

[7] C. Gallert, "Degradation of Latex and of Natural Rubber by Streptomyces Strain La 7," Systematic and Applied Microbiology, vol. 23, 2000, pp. 433-441. https://doi.org/10.1016/S0723-2020(00)80075-2

[8] E. M. A. Ibrahim, M. Arenskotter, H. Luftmann, and A. Steinbüchel, "Identification of poly (cis-1, 4-isoprene) degradation intermediates during growth of moderately thermophilic actinomycetes on rubber and cloning of a functional lcp homologue from Nocardia farcinica strain E1," Applied and Environmental Microbiology, vol. 72, 2006, pp. 3375-3382. https://doi.org/10.1128/AEM.72.5.3375-3382.2006

[9] A. M. Ismail, H. N. Mohamed, and M. A. Shoreit, "Degradation of Ficus elastica rubber latex by Aspergillus terreus, Aspergillus flavus and Myceliophthora thermophile," International biodeterioration \& biodegradation, vol. 78, 2013, pp. 82-88. https://doi.org/10.1016/j.ibiod.2012.12.009

[10] A. Linos, and A. Steinbuchel, "Microbial degradation of natural and synthetic rubbers by novel bacteria belonging to the genus Gordona," Kautschuk Gummi Kunststoffe, vol. 51, 1998, pp. 498-499.

[11] A. Linos, M. M. Berekaa, A. Steinbüchel, K. K.Kim, C. Spröer, and R. M. Kroppenstedt, "Gordonia westfalica sp. nov., a novel rubberdegrading actinomycete," International Journal of Systematic and Evolutionary Microbiology, vol. 52, 2002, pp. 1133-1139. https://doi.org/10.1099/00207713-52-4-1133

[12] K. Rose, and A. Steinbuchel, "Biodegradation of natural rubber and related compounds: recent insights into a hardly understood catabolic capability of microorganisms," Applied and Environmental Microbiology, vol. 71, 2005, pp. 2803-2812.

https://doi.org/10.1128/AEM.71.6.2803-2812.2005
[13] A. Shah, F. Hasan, Z. S. Mutiullah, and A. Hameed, "Degradation of polyisoprene rubber by newly isolated Bacillus sp.AF-666 from soil," Applied Biochemistry and Microbiology, vol. 48, 2012, pp. 37-42. https://doi.org/10.1134/S0003683812010140

[14] A. Tsuchii, T. Suzuki, and K. Takeda, "Microbial degradation of natural rubber vulcanisates," Applied and Environmental Microbiology, vol. 50, 1985, pp. 965-970.

[15] A. Tsuchii, and K. Takeda, "Rubber degrading enzyme from bacterial culture," Applied and Environmental Microbiology, vol. 56, 1990, pp. 269-274.

[16] M. Yikmis, and A. Steinbüchel, "Historical and Recent Achievements in the Field of Microbial Degradation of Natural and Synthetic Rubber," Applied and Environmental Microbiology, vol. 78, 2012, pp. 45434551. https://doi.org/10.1128/AEM.00001-12

[17] G. Nayanashree, and B. Thippeswamy, "Natural rubber degradation by laccase and manganese peroxidase enzymes of Penicillium chrysogenum," International Journal of Environmental Science and Technology, vol. 12, 2015, pp. 2665-2672 https://doi.org/10.1007/s13762-014-0636-6

[18] International Rubber Study Group, "STATISTICAL SUMMARY OF WORLD RUBBER SITUATION," Rubber Statistical Bulletin, 2016.

About Author (s):

Isolation of rubber degradation bacteria from soils
for complete natural rubber degradation

